\title{
RECEPTOR ACTIVATOR OF NUCLEAR TRANSCRIPTION FACTOR NF- $\kappa B$ (RANK), ITS LIGAND (RANKL) AND NATURAL INHIBITOR OSTEOPROTEGERIN (OPG) IN BLOOD SERUM OF PRIMARY BONE TUMOR PATIENTS: ASSOCIATION WITH CLINICOPATHOLOGICAL FEATURES AND INFLAMMATORY CYTOKINES LEVELS
}

\author{
N.E. Kushlinskii, E.S. Gershtein*, Yu.S. Timofeev, \\ E.A. Korotkova, I.V. Babkina, O.I. Kostyleva, Yu.N. Solovyev
}

\author{
N. N. Blokhin Russian Cancer Research Center of the Russian Ministry of Public Health, Moscow, Russia
}

\begin{abstract}
RANK/RANKL/OPG system (the key regulator of bone homeostasis) component levels were measured in blood serum of 199 patients with primary bone tumors and tumor-like lesions: 121 with bone sarcomas (53 osteosarcoma, 46 chondrosarcoma, 12 chordoma, 8 Ewing sarcoma), 32 with borderline giant cell bone tumor (GCBT), 46 with benign bone neoplasms; 131 persons comprised the control group. OPG, sRANKL, sRANK, IL-6, 8, 16 serum levels were measured by standard ELISA kits. Giant-cell bone tumor (GCBT) manifesting high osteoclastogenic and osteolytic activities was characterized by high serum content of all three components studied and the highest sRANKL/OPG ratio. The group of patients with various benign bone tumors and tumor-like lesions displayed similar to GCBT, but lower indices. Malignant bone tumor patients could be divided into 2 subgroups with opposite characteristics: osteosarcoma and Ewing sarcoma patients demonstrated low sRANK and high sRANKL levels, while chondrosarcoma and chordoma patients, on the contrary - high sRANK and low sRANKL levels. The highest IL-6 levels were revealed in GCBT patients, while serum $I L-8$ and IL-16 did not differ between groups. Thus, disturbances in osteolysis activators and inhibitors balance in blood serum of primary bone tumor patients were revealed. Their extent depended on neoplasm character (malignant, borderline, or benign) and histological structure of malignant sarcomas. Most prominent changes were found in GCBT characterized by active bone destruction and an accepted target of anti-RANKL antibody denosumab treatment. Hence, the proteins studied can be regarded as promising serologic markers and therapeutic targets in this rare disease.
\end{abstract}

Key words: Blood serum, denosumab, giant-cell bone tumor, osteoprotegerin, primary bone tumors, RANK, RANKL

DOI: $10.21175 /$ RadProc.2017.51

\section{INTRODUCTION}

RANK/RANKL/OPG ligand receptor system is the key player in bone tissue homeostasis directly regulating osteoclast differentiation and osteolysis [1]. The central tier of this system is receptor activator of nuclear transcription factor NF- $\mathrm{KB}$ (RANK) - type I transmembrane protein, a member of tumor necrosis factor receptors superfamily (TNFRSF) characterized by the absence of tyrosine kinase activity in its intracellular domain. RANK is predominantly expressed on osteoclast precursor cells. The sole ligand interacting with the extracellular domain of RANK (RANKL) belongs to TNF family and is also a transmembrane protein primarily expressed on the surface of activated T-cells, bone marrow stromal cells and osteoblasts. Soluble forms of RANKL (sRANKL) also do exist emerging either as a result of proteolytic cleavage of transmembrane protein, or from alternative splicing of its mRNA. Binding of both transmembrane and soluble forms of RANKL with RANK induces receptor trimerization that through a complicated chain of adapter molecules stimulates various $\mathrm{NF}-\kappa \mathrm{B}$ activating signaling pathways leading to the initiation of osteoclast formation from precursor cells and activation of mature osteoclasts. The natural RANKL antagonist is osteoprotegerin (OPG, TNFRSF11B) - socalled "decoy receptor", soluble homolog of RANK with molecular mass of $60 \mathrm{kD}$ as a monomer and $120 \mathrm{kD}$ as a disulfide homodimer. OPG is primarily secreted by bone marrow stromal cells and osteoblasts and blocks RANK-RANKL interaction by binding of the latter.

RANKL/OPG ratio is differentially regulated in physiologic and pathologic conditions, and disturbances in the balance of RANK/RANKL/OPG system components are associated with many pathologic processes imposed by bone remodeling disorders including osteoporosis and rheumatoid arthritis [2]. Changes of bone remodeling are also involved in some processes associated with tumor growth such as bone destruction, metastasis development and disease progression [3]. Signals

*esgershtein@gmail.com 
affecting RANKL/OPG ratio are variegated and depend on the type and nosologic peculiarities of bone damaging tumor [1]. Various cytokines and molecular factors such as interleukins (IL) $1 \beta, 6,8,11,16$, macrophage inflammatory protein $1 \alpha, \mathrm{TNF} \alpha$, prostaglandin E, are able to enhance RANKL production by stromal cells of bone marrow microenvironment including osteoblasts. On the other hand, tumor production of OPG playing RANKL trap role can be reduced by a decrease of its synthesis or an activation of its degradation.

Increased expression and/or signaling activity of RANKL was revealed in different solid tumors, and RANKL produced by tumor cells could enhance osteoclastogenesis in vitro allowing to surmise direct influence of tumor cells localized in bone tissue on this process. Involvement of RANK/RANKL/OPG system in the formation of bone metastasis of various tumors is practically established [4]; however, its role in the development of primary bone neoplasms is still studied insufficiently. High expression of factors responsible for osteoclastogenesis (RANKL, M-CSF) by osteosarcoma cell lines MG63 and Saos-2 was demonstrated in in vitro experiments [5, 6], and a clinical study has demonstrated a significant relationship between high RANKL expression in the tumor and a poor response of osteosarcoma patients to neoadjuvant chemotherapy: high RANKL expression levels were associated with low 5-years' overall survival [7]. Increased expression of RANK/RANKL/OPG system components was also found in chondrosarcoma [8], Ewing sarcoma [9], and some bone tissue benign tumor-like lesions [10].

Attempts to apply synthetic and natural inhibitors of RANK/RANKL interaction for the suppression of osteoclast formation and osteolysis in different pathologies accompanied by bone tissue destruction were undertaken more than once, but the majority of those attempts have not brought expected results [11]. The most successful inhibitor of RANK/RANKL signaling activity was proved to be denosumab - fully humanized antiRANKL monoclonal antibody binding the ligand with high affinity and specificity and preventing, as a result, RANK activation [12].

Thus, clinical laboratory investigation of the role of RANK/RANKL/OPG system in primary bone tumors is promising for the development of new diagnostic options and selective application of specific molecular targeted chemotherapy. It should be emphasized that the majority of publications devoted to this problem describe either tissue expression of these markers, or experiments performed on cell cultures, while practically no results of RANK/RANKL/OPG blood serum concentration measurement in patients with primary bone tumors are presented in modern literature.

In our previous preliminary studies certain trends towards changes of RANK/RANKL/OPG balance in blood serum of patients with borderline, malignant and benign bone tumors requiring further investigation and confirmation were demonstrated $[11,13]$. By now, both the study and the control groups were considerably enlarged allowing the performance of more detailed and substantiated analysis.

So, the objective of this study was RANK/RANKL/OPG and key inflammatory cytokines
(IL-6, 8 and 16) determination in blood serum of patients with malignant, borderline and benign bone tumors and tumor-like lesions, and analysis of associations between these markers and principal clinical and pathological characteristics of bone tumors.

\section{MATERIALS AND METHODS}

Study group comprised 199 patients with various primary bone neoplasms: 96 female aged $5-76$ (median - 43) and 103 male aged 5 - 74 (median - 35) undergoing treatment in the N.N. Blokhin Russian Cancer Research Center. Control group comprised 72 women aged 5 - 75 (median - 36) and 59 men aged $3-76$ (median - 28). None of the patients received any specific treatment before biochemical examination, and clinical and radiographic diagnosis of bone tumor was always confirmed by the data of pathologic examination. The study design conformed to the requirements of the Institution's Ethical Committee.

Bone tumor patients were segregated into 3 groups: 1) 121 patient with malignant neoplasm (osteosarcoma (OS) - 53, chondrosarcoma (ChS) - 48, chordoma (Chdm) - 12; Ewing sarcoma (ES) - 8); 2) 32 patients with borderline bone tumors (all with giant-cell bone tumor - GCBT); 3) 46 patients with various benign bone tumors and tumor-like lesions (bone fibrous dysplasia, enchondroma, aneurismal bone cyst, chondromyxoid fibroma, osteoblastoma, benign fibrous histiocytoma, osteochondroma).

Concentration of the proteins studied in blood serum obtained by standard technique before the onset of specific treatment was measured by standard commercial ELISA kits: "ampli-sRANKL" and "Osteoprotegerin" (Biomedica Medizinprodukte, Austria), RANK ELISA (Uscn Life Science Inc, China), "Human Il-6 Platinum ELISA" and "Human Il-8/NAP1 Platinum ELISA" ("Bender MedSystems", Austria), "Human IL-16" ("Invitrogen", USA) according to the manufacturers' instructions. The results were measured at fully automated microtitration plate analyzer BEP 2000 Advance (Siemens Healthcare Diagnostics, Germany).

Statistical evaluation of the data was performed with the help of "Statistica 7.0" program package. Since the distribution of the parameters studied did not conform to Gauss distribution in most cases, nonparametric criteria were applied for group comparisons and correlation analysis: Mann-Whitney test, KruskalWallis test, Spearman rank correlation test (R). The differences and correlations were considered significant at $\mathrm{p}<0.05$. Medians and upper and lower quartile levels are presented in both tables.

\section{RESULTS AND DISCUSSION}

Measurable soluble receptor (sRANK) concentrations were detected in blood serum of $59 \%$ benign bone neoplasms patients (median - 0.82 $\mathrm{ng} / \mathrm{ml}$ ) and $54 \%$ GCBT patients (median $-1.08 \mathrm{ng} / \mathrm{ml}$ ). Meanwhile, this marker was found in only $45 \%$ of patients with malignant tumors and in $49 \%$ control samples. No statistically significant differences in 
sRANK levels between these four study groups were revealed (Table 1).

When sRANK concentration was analyzed in relation to histological type of malignant bone tumors it was found that this protein was present in blood serum of $39 \%$ OS patients, $56 \% \mathrm{ChS}$ patients (median - $0.54 \mathrm{ng} / \mathrm{ml}$ ), 50\% Chdm patients (median - 0.62 $\mathrm{ng} / \mathrm{ml}$ ) and only $25 \%$ ES patients (Table 1 ). Thus, we have confirmed our previous reports about low serum sRANK levels in bone sarcomas patients, particularly in those with OS and ES, and its highest level in GCBT patients.

Soluble ligand (sRANKL) was detected in blood serum of the majority of benign bone neoplasms and GCBT patients (89 and 90\%; medians - 0.16 and 0.22 $\mathrm{pmol} / \mathrm{l}$ respectively), as well as in $76 \%$ control persons (median - $0.14 \mathrm{pmol} / \mathrm{l}$ ) and $69 \%$ bone sarcomas patients (median - $0.12 \mathrm{pmol} / \mathrm{l}$ ) (Table 1). The level of this protein in blood serum of GCBT patients was significantly higher than in control group and in malignant bone tumor patients ( $\mathrm{p}<0.05$ in both cases).

Taking into consideration the histological type of malignant neoplasms, the following data were obtained: sRANKL was revealed in $75 \%$ OS (median $0.12 \mathrm{pmol} / \mathrm{l}$ ), 58\% ChS and CHdm (medians - 0.06 and $0.03 \mathrm{pmol} / \mathrm{l}$ respectively), and in 100\% ES patients (median - $0.18 \mathrm{pmol} / \mathrm{l}$ ). Significant differences were found between $\mathrm{ChS}$ and GCBT, Chdm and GCBT, and $\mathrm{ChS}$ and control group (Table 1).

Table 1. RANK/RANKL/OPG component concentrations

in blood serum of patients with different bone neoplasms and healthy persons*

\begin{tabular}{|c|c|c|c|c|c|}
\hline Group & $\mathbf{N}$ & sRANK ng/ml & $\begin{array}{c}\text { SRANKL } \\
\text { pmol/1 }\end{array}$ & $\begin{array}{c}\text { OPG } \\
\text { pmol/1 }\end{array}$ & SRANKL/OPG \\
\hline $\begin{array}{l}\text { All malignant } \\
\text { tumors (MT) } \\
\text { including: }\end{array}$ & 121 & $\begin{array}{c}0 \\
0-1.15 \\
\end{array}$ & $\begin{array}{c}0.12 \\
0-0.32 \\
\end{array}$ & $\begin{array}{c}3.14 \\
0.99-4.57 \\
\end{array}$ & $\begin{array}{c}0.03 \\
0-0.12 \\
\end{array}$ \\
\hline $\begin{array}{l}\text { Osteosarcoma } \\
(\mathrm{OS})\end{array}$ & 53 & $\begin{array}{c}O \\
O-O .1 O\end{array}$ & $\begin{array}{c}0.12 \\
0.02-0.32\end{array}$ & $\begin{array}{c}1.68 \\
0.85-4.35 \\
\end{array}$ & $\begin{array}{c}0.04 \\
0-0.14\end{array}$ \\
\hline $\begin{array}{l}\text { Chondrosarcoma } \\
(\mathrm{ChS})\end{array}$ & 48 & $\begin{array}{c}0.54 \\
o-1.61 \\
\end{array}$ & $\begin{array}{c}0.06 \\
o-0.24 \\
\end{array}$ & $\begin{array}{c}3.33 \\
2.0-4.57 \\
\end{array}$ & $\begin{array}{c}0.01 \\
o-0.09 \\
\end{array}$ \\
\hline $\begin{array}{l}\text { Chordoma } \\
\text { (Chdm) }\end{array}$ & 12 & $\begin{array}{c}0.62 \\
o-0.82\end{array}$ & $\begin{array}{c}0.03 \\
o-0.25\end{array}$ & $\begin{array}{c}4.04 \\
2.57-4.69\end{array}$ & $\begin{array}{c}0.005 \\
0-0.12\end{array}$ \\
\hline $\begin{array}{l}\text { Ewing sarcoma } \\
(E S)\end{array}$ & 8 & $\begin{array}{c}O \\
O-O .4 O\end{array}$ & $\begin{array}{c}0.18 \\
0.10-0.53\end{array}$ & $\begin{array}{c}3.39 \\
0.67-5.82\end{array}$ & $\begin{array}{c}0.07 \\
0.03-0.28\end{array}$ \\
\hline $\begin{array}{l}\text { Boderline tumors } \\
\text { - GCBT }\end{array}$ & 32 & $\begin{array}{c}1.08 \\
0-1.50\end{array}$ & $\begin{array}{c}0.22 \\
0.05-0.49\end{array}$ & $\begin{array}{c}3.08 \\
1.49-4.70\end{array}$ & $\begin{array}{c}0.07 \\
0.03-0.20\end{array}$ \\
\hline $\begin{array}{l}\text { Benign neoplasms } \\
\text { (BN) }\end{array}$ & 46 & $\begin{array}{c}0.82 \\
0-0.94 \\
\end{array}$ & $\begin{array}{c}0.16 \\
0.06-0.28 \\
\end{array}$ & $\begin{array}{c}3.11 \\
1.52-4.81 \\
\end{array}$ & $\begin{array}{c}0.05 \\
0.01-0.15 \\
\end{array}$ \\
\hline Control (C) & 131 & $\begin{array}{c}0 \\
0-0.71 \\
\end{array}$ & $\begin{array}{c}0 \\
0-0.26 \\
\end{array}$ & $\begin{array}{c}2.91 \\
1.35-5.10 \\
\end{array}$ & $\begin{array}{c}0.03 \\
0-0.08 \\
\end{array}$ \\
\hline P(Mann-Whitney) & & All $>0.05$ & $\begin{array}{c}G C B T \text { vs } C \text { and } G C B T \\
\text { vs } M T<0.05 \\
\text { ChS vs } C, \text { ChS vs } \\
\text { GCBT and } \\
\text { Chdm vs GCBT } \\
<0.05\end{array}$ & $\begin{array}{c}\text { OS vs } C \text { and OS vs ChS } \\
<0.05\end{array}$ & $\begin{array}{c}\text { GCBT vs Cand } \\
\text { GCBT vs } M T<0.05 \\
\text { ChS vs GCBT <0.01; } \\
\text { ChS vs BN, } \\
\text { ChS vs ES, } \\
\text { Chdm vs GCBT and } \\
\text { Chdm vs ES <0.05 }\end{array}$ \\
\hline
\end{tabular}

* Medians and upper and lower quartile levels are presented

Natural RANKL/RANK interaction inhibitor OPG was detected in $93 \%$ control samples, $98 \%$ benign bone neoplasms, 97\% GCBT and 96\% malignant bone tumor patients' sera. The medians did not differ significantly and comprised 2.91; 3.11; 3.08 and $3.14 \mathrm{pmol} / \mathrm{l}$ respectively (Table 1). Hence, serum OPG level did not depend on the character of bone neoplasm (malignant, borderline or benign) and was practically similar to control.

On the other hand, analysis of OPG levels in relation to histological type of malignant bone tumors revealed a considerable decrease of its serum level in OS patients as compared to both those with all other tumor types (including benign and GCBT) and control group - the frequency of OPG detection in OS patients comprised $92 \%$, but its median concentration in blood serum was as low as $1.68 \mathrm{pmol} / \mathrm{l}$ (Table 1). At the same time OPG was detected in the sera of all patients with Chdm and ES and in $98 \%$ of those with ChS (medians - 4.04; $3.39 ; 3.33 \mathrm{pmol} / \mathrm{l}$ respectively). The decrease of serum OPG in OS patients was statistically significant in comparison to $\mathrm{ChS}$ patients and control persons $(\mathrm{p}<0.05)$.

As was already mentioned, an important index of osteoclastogenesis activity could be the ratio between RANK activator (sRANKL) and inhibitor (OPG) in blood serum. In our study group sRANKL/OPG ratio was found to be the highest in GCBT and ES patients (both medians - 0.07), and the lowest - in Chdm (o.005) and ChS (0.01) patients (Table 1).

Correlative associations between the parameters studied were analyzed. Statistically significant, but rather weak positive correlation between OPG and sRANK levels $(\mathrm{R}=0.39$; $\mathrm{p}<0.0001)$ was observed in the total study group including control persons. When the groups were analyzed separately, Spearman coefficient $\mathrm{R}$ comprised only $0.21(\mathrm{p}=0.049)$ in the control group, but $0.50(\mathrm{p}<0.0001)$ - in patients with malignant bone tumors, and $\mathrm{R}$ was equal to $0.49(\mathrm{p}=0.015)$ and 0.45 $(\mathrm{p}=0.013)$ in patients with GCBT and benign neoplasms respectively. Thus, the linkage between receptor (RANK) and its natural inhibitor (OPG) serum 
levels enhanced in patients with malignant and borderline bone tumors as compared to healthy (tumor-free) persons and patients with benign bone tumors and tumor-like lesions.

Summarizing the results of our study, certain peculiarities of various bone neoplasms can be emphasized:

1. Borderline GCBT manifesting high osteoclastogenic and osteolytic activity is characterized by high levels of all RANKL/RANK/OPG system components and the highest sRANKL/OPG ratio in patients' serum.

2. The variegated group of patients with benign bone tumors and tumor-like lesions has similar to those with GCBT, but lower markers ratios.

3. In the malignant bone tumor group, two subgroups with opposite characteristics can be allocated: OS and ES patients display low sRANK and high sRANKL levels in blood serum, while ChS and Chdm patients, on the contrary, - high sRANK and low SRANKL levels. At the same time, a significant decrease of serum OPG is observed in OS patients as compared to all other patients' groups and control. This phenomenon may be a sign of relatively high osteolytic activity of OS despite being lower than in patients with other neoplasm sRANK levels.

Serum inflammatory cytokines - IL-6, 8 and 16 levels were measured in blood serum of 163 bone neoplasms patients and 71 practically healthy persons (Table 2). Statistically significant differences between groups were found only for IL-6: its level was increased in blood serum of malignant and borderline bone tumor patients as compared to control group and patients with benign bone neoplasms. IL-6 level was also markedly higher in GCBT patients than in those with malignant tumors (medians 0.81 and $0.49 \mathrm{pg} / \mathrm{ml}$ respectively; $\mathrm{p}>0.05$ ). A trend towards higher IL-16 level in blood serum of malignant bone tumor patients than in all other study groups can also be noted but this difference did not reach the level of statistical significance.

Table 2. IL- 6, 8 and 16 concentrations in blood serum of primary bone neoplasms patients and healthy persons

\begin{tabular}{|c|c|c|c|c|}
\hline Group & $\mathbf{N}$ & $\begin{array}{c}\text { IL-6 } \\
\mathrm{pg} / \mathrm{ml}\end{array}$ & $\begin{array}{c}\text { IL-8 } \\
\mathrm{pg} / \mathrm{ml}\end{array}$ & $\begin{array}{l}\text { IL-16 } \\
\mathrm{pg} / \mathrm{ml}\end{array}$ \\
\hline Malignant tumors (MT) & 101 & $\begin{array}{c}0.49 \\
0-1.84 \\
\end{array}$ & $\begin{array}{c}12.0 \\
6.93-20.2\end{array}$ & $\begin{array}{c}36.0 \\
16.9-50.8 \\
\end{array}$ \\
\hline Borderline tumors - GCBT & 32 & $\begin{array}{c}0.81 \\
0.09-1.92\end{array}$ & $\begin{array}{c}10.1 \\
5.78-15.2\end{array}$ & $\begin{array}{c}23.6 \\
7.97-43.9\end{array}$ \\
\hline Benign neoplasms (BN) & 30 & $\begin{array}{c}0.11 \\
0-0.40\end{array}$ & $\begin{array}{c}7.79 \\
2.89-14.5\end{array}$ & $\begin{array}{c}19.1 \\
0-54.7\end{array}$ \\
\hline Control (C) & 71 & $\begin{array}{c}0.02 \\
0-0.18 \\
\end{array}$ & $\begin{array}{c}7.80 \\
0-18.2 \\
\end{array}$ & $\begin{array}{c}26.1 \\
16.7-40.1\end{array}$ \\
\hline P (Mann-Whitney) & & $\begin{array}{c}G C B T \text { vs } C \text { and } M T \text { vs } C \\
<O .0001 \\
\text { GCBT vs BN and } M T \text { vs BN } \\
<0.05\end{array}$ & All $>0.05$ & All $>0.05$ \\
\hline
\end{tabular}

* Medians and upper and lower quartile levels are presented

The analysis of associations between interleukins levels in patients' sera and histological type of malignant bone tumors did not reveal any statistically significant differences. Increase of IL-6 serum level in relation to control was found in all malignant tumor types, the highest level being found in ES (median - 3.1 $\mathrm{pg} / \mathrm{ml}$ ). In ChS patients IL-6 level was also significantly higher than in patients with benign neoplasms (medians - 0.49 and $0.11 \mathrm{pg} / \mathrm{ml}$ respectively; $\mathrm{p}<0.05$ ). Similarly, serum IL-16 was higher in ChS patients than in patients with benign neoplasms (medians - 48.2 and $19.1 \mathrm{pg} / \mathrm{ml}$ respectively; $\mathrm{p}<0.05$ ).

No associations were found between serum levels of all markers studied (both RANK/RANKL/OPG system components, and interleukins) and type of affected bone, tumor size, localization or histological grade (data not shown).

\section{CONCLUSIONS}

Thus, marked disturbances of the balance between osteolysis activators and inhibitors in blood serum of primary bone tumor patients were revealed. The extent and direction of these changes depended on tumor character (malignant, borderline or benign) and histological type of malignant tumors. These disorders might be imposed predominantly by the changes occurring directly in tumor tissue, but we cannot ignore the fact that serum levels of RANK/RANKL/OPG components, as well as the level of any other serological marker, cannot be completely determined by the secretion of corresponding protein from tumor cells. It depends on various physiological factors, on probable production of proteins studied by other tissues, and on the presence of concomitant diseases, in particular, osteoporosis and inflammatory processes $[14,15]$.

The most noteworthy changes were found in patients with GCBT - a borderline bone neoplasm characterized by intensive osteolysis, as well as in patients with chondroid type malignant tumors chondrosarcoma and chordoma. These observations match the known fact that XGEVA ${ }^{\circledR}$ (denosumab) - a molecular targeted preparation composed of antiRANKL monoclonal antibodies - was in 2013 recommended by the American Food and Drug Administration for the treatment of inoperable GCBT $[16,17]$. It was shown that the clinical effect of denosumab observed in a considerable part of the patients was accompanied by more than $90 \%$ decrease of the number of tumor-associated giant cells and a decrease of the number of stromal cells [18]. RANK/RANKL interaction inhibitors are also considered as new approaches to the treatment of 
chordoma [19] and some benign bone lesions [10]. And an effect of denosumab combination with protein kinase inhibitor sorafenib in a patient with unresectable chemorefractory osteoblastic osteosarcoma was reported [20]. Taken together, our data and published results of successful application of RANK/RANKL interaction inhibitors in clinical practice evidence in favor of further investigation of RANK/RANKL/OPG system components in primary bone tumor patients not only on tissue level, but also in peripheral blood.

Acknowledgement: The paper is a part of the research done within the project № 15-03-00521 supported by the Russian Foundation for Basic Research.

\section{REFERENCES}

1. W. C. Dougall, "RANKL signaling in bone physiology and cancer," Curr. Opin. Support. Palliat. Care, vol. 1, no. 4 , pp. 317-322, Dec. 2007.

DOI: 10.1097/SPC.obo13e3282f335be PMid: 18685382

2. A. Leibbrandt, J. M. Penninger, "RANKL/RANK as key factors for osteoclast development and bone loss in arthropathies," Adv. Exp. Med. Biol., vol. 649, pp. 100$113,2009$.

DOI: $10.1007 / 978-1-4419-0298-6 \_7$ PMid:19731623

3. L. Kiesel, A. Kohl, "Role of the RANK/RANKL pathway in breast cancer," Maturitas, vol. 86, pp. 10-16, Apr. 2016.

DOI: 10.1016/j.maturitas.2016.01.001 PMid:26921922

4. A. Kukita, T. Kukita, "Multifunctional properties of RANKL/RANK in cell differentiation, proliferation and metastasis," Future Oncol., vol. 9, no. 11, pp. 16091622, Nov. 2013.

DOI: $10.2217 /$ fon. 13.115

PMid: 24156322

5. J. Costa-Rodrigues, C. A. Teixeira, M. H. Fernandes, "Paracrine-mediated osteoclastogenesis by the osteosarcoma MG63 cell line: is RANKL/RANK signalling really important?" Clin. Exp. Metastasis, vol. 28, no. 6, pp. 505-514, Aug. 2011.

DOI: $10.1007 / \mathrm{s} 10585-011-9387-7$ PMid: 21479680

6. K. Mori, B. Le Goff, M. Berreur, A. Riet, A. Moreau, F. Blanchard et al., "Human osteosarcoma cells express functional receptor activator of nuclear factor-kappa B," J. Pathol., vol. 211, no. 5, pp. 555-562, Feb. 2007.

DOI: $10.1002 /$ path.2140 PMid: 17323424

7. J. A. Lee, J. S. Jung, D. H. Kim, J. S. Lim, M. S. Kim, C. B. Kong et al., "RANKL expression is related to treatment outcome of patients with localized, highgrade osteosarcoma," Pediatr. Blood Cancer, vol. 56, no. 5, pp. 738-743, May 2011.

DOI: $10.1002 / \mathrm{pbc} .22720$

PMid: 21370405

8. Z. Wang, L. Ding, S. Zhang, T. Jiang, Y. Yang, R. Li, "Effects of icariin on the regulation of the OPG-RANKLRANK system are mediated through the MAPK pathways in IL-1 $\beta$-stimulated human SW1353 chondrosarcoma cells," Int. J. Mol. Med., vol. 34, no. 6, pp. 1720-1726, Sep. 2014.

DOI: 10.3892/ijmm.2014.1952

PMid: 25270538

9. R. Taylor, H. J. Knowles, N. A. Athanasou, "Ewing sarcoma cells express RANKL and support osteoclastogenesis," J. Pathol., vol. 225, no. 2, pp. 195202, Oct. 2011.

DOI: $10.1002 /$ path. 2869

PMid: 21547906

10. D. W. Pelle, J.W. Ringler, J. D. Peacock, K. Kampfschulte, D. J. Scholten 2nd, M. M. Davis et al., "Targeting receptor-activator of nuclear kappaB ligand in aneurysmal bone cysts: verification of target and therapeutic response," Transl. Res., vol. 164, no. 2, pp. 139-148, Aug. 2014.

DOI: 10.1016/j.trsl.2014.03.005

PMid: 24726460

11. Е. С. Герштейн, Ю. С. Тимофеев, А.А. Зуев, Н. Е. Кушлинский, “Лиганд-рецепторная система RANK/RANKL/OPG и ее роль при первичных новообразованиях костей (анализ литературы и собственные результаты)," Успехи молекулярной онкологии, т. 2, по. 3, стр. 51-59, 2015. (E. S. Gershtein, Y. S. Timofeev, A. A. Zuev, N. E. Kushlinskii,"RANK/RANKL/OPG LigandReceptor systems and its role in primary bone neoplasms (literature analysis and own data)," Advances in molecular oncology, vol. 2, no. 3, pp. 5159, 2015.)

DOI: $10.17650 / 2313-805 X .2015 \cdot 2 \cdot 3.51-59$

12. J.S. Burkiewicz, S. L. Scarpace, S. P. Bruce, "Denosumab in osteoporosis and oncology," Ann. Pharmacother., vol. 43, no. 9, pp. 1445-1455, Jul. 2009. DOI: 10.1345/aph.1M102

PMid: 19622756

13. N. E. Kushlinskii, Y. S. Timofeev, Y. N. Solov'ev, E. S. Gerstein, N. V. Lyubimova, I. V. Bulycheva, "Components of the RANK/RANKL/OPG System, IL-6, IL-8, IL-16, MMP-2, and Calcitonin in the Sera of Patients with Bone Tumors," Bulletin of Experimental Biology and Medicine, vol. 157, no. 4, pp. 520-523, Aug. 2014.

DOI: 10.1007/s10517-014-2605-y

PMid: 25110097

14. D. M. Findlay, G. J. Atkins, "Relationship between serum RANKL and RANKL in bone," Osteoporos. Int. vol. 22, no. 10, pp. 2597-2602, Oct. 2011.

DOI: $10.1007 /$ so0198-011-1740-9

PMid: 21850548

15. D. Wagner, A. Fahrleitner-Pammer, "Levels of osteoprotegerin (OPG) and receptor activator for nuclear factor kappa B ligand (RANKL) in serum: are they of any help?" Wien Med. Wochenschr., vol. 160, no. 17-18, pp. 452-457, Sep. 2010.

DOI: $10.1007 / \mathrm{s} 10354-010-0818-\mathrm{x}$

PMid: 20714810

16. A. S. Singh, N. S. Chawla, S. P. Chawla, "Giant-cell tumor of bone: treatment options and role of denosumab," Biologics, vol. 9, pp. 69-74, Jul. 2015.

DOI: 10.2147/BTT.S57359

PMid: 26203221 PMCid: PMC4507456

17. A. Lopez-Pousa, J. M. Broto, T. Garrido, J. Vazquez, "Giant cell tumour of bone: new treatments in development," Clin. Transl. Oncol., vol. 17, no. 6, pp. 419-430, Jun. 2015.

DOI: $10.1007 / \mathrm{s} 12094-014-1268-5$

PMid: 25617146 PMCid: PMC4448077

18. D. G. Branstetter, S. D. Nelson, J. C. Manivel, J. Y. Blay, S. Chawla, D. M. Thomas et al., "Denosumab induces tumor reduction and bone formation in patients with giant-cell tumor of bone," Clin. Cancer Res., vol. 18, no. 16, pp. 4415-4424, Aug. 2012.

DOI: 10.1158/1078-0432.CCR-12-0578

PMid: 22711702

19. F. C. Lam, J. E. Arle, P. A. Glazer, E. M. Kasper, "Primary Extradural Tumors of the Spine - Case Review with Evidence-guided Management," Surg. Neurol. Int., vol. 5, no. 7, pp. S373-375, Aug. 2014.

DOI: $10.4103 / 2152-7806.139673$ 
PMid: 25289164

PMCid: PMC4173213

20. R. Cathomas, C. Rothermundt, B. Bode, B. Fuchs, R. von Moos, M. Schwitter, "RANK ligand blockade with denosumab in combination with sorafenib in chemorefractory osteosarcoma: a possible step forward?” Oncology, vol. 88, no 4, pp. 257-260,

Dec. 2014

DOI: 10.1159/000369975

PMid: 25531914 